\title{
Attitudes and perceptions influence recreational angler support for shark conservation and fisheries sustainability
}

\author{
J. Marcus Drymon ${ }^{\mathrm{a}, \mathrm{b}, *}$, Steven B. Scyphers ${ }^{\mathrm{c}}$ \\ a Department of Marine Sciences, University of South Alabama, LSCB Room 25, Mobile, AL 36688, USA \\ b Center for Ecosystem Based Fishery Management, Dauphin Island Sea Lab, 101 Bienville Boulevard, Dauphin Island, AL 36528, USA \\ c Department of Marine and Environmental Sciences, Northeastern University, Marine Science Center, 430 Nahant Road, Nahant, MA 01908, USA
}

\begin{abstract}
A B S T R A C T
Despite the perilous status of many shark populations, rallying support for their conservation has been challenging, due in part to both long held negative perceptions and desire for shark fisheries. Recreational anglers are often advocates of conservation and can act as valuable partners with resource managers in developing fisheries management and conservation strategies. However, understanding their attitudes and perceptions, particularly towards resource status and management, is essential to developing successful management strategies and predicting outcomes. As a case study for assessing the complex challenges of sustainable shark fisheries, Florida recreational anglers were surveyed to understand how attitudes and perceptions influenced their willingness to donate for shark 1) conservation and protection or 2) fisheries sustainability. Overall, recreational angler willingness to donate was $25.5 \%$, but attitudes and perceptions helped explain dramatic divides. For instance, willingness to donate was only $6 \%$ among the subset of anglers that perceived a growing large coastal shark population as a threat to recreational fishing opportunities. Highest support for shark conservation was shown by anglers who value seeing sharks in the wild (41.4\%), and even more so among individuals who occasionally target sharks while fishing recreationally (65.8\%). Pervasive among anglers unwilling to donate was a perception that shark populations were increasing, and thus not in need of further protection. These findings illustrate attitudes and perceptions that challenge shark conservation and fisheries management, as well as the critical importance of engaging anglers when developing strategies that rely on the recreational angling community for support.
\end{abstract}

\section{Introduction}

Recent estimates of global extinction risk suggest that a quarter of all sharks and rays are threatened according to IUCN red list criteria [1]. Much of this extinction risk is the result of overfishing, where current exploitation rates often exceed the rebound potential of many shark species [2]. The relatively slow growth and low reproductive rates of sharks makes them particularly vulnerable to population declines from both direct and incidental harvest [3]. Reversing population level declines shown for many species will require a suite of approaches, including protection of critical habitats, long-term population monitoring programs, and reductions in fishing mortality [4]. Since many of these management actions require substantial societal and stakeholder support, public awareness of populations in peril and attitudes favoring their recovery are essential for the conservation and sustainability of shark populations $[5,6]$.
Long-standing negative notions held by the general public have hampered support for shark conservation $[7,8]$. These notions are spurred by popular media coverage of sharks that often focuses more on the risk sharks pose to humans rather than their perilous conservation status $[9,10]$. Disseminating accurate information about sharks can alter public perception; for example, less knowledge about sharks has been shown to lead to negative attitudes towards sharks [8], whereas increased knowledge about sharks leads to increased concern regarding their protection [11,12]. Similarly, recent findings suggest that personal experience with sharks may act to dampen these negative perceptions [7,13]; however, the degree to which knowledge or personal experience with sharks leads to conservation action is unclear.

Recreational fishing for sharks is increasing in popularity [14], and may provide opportunities for personal experiences that lead to positive conservation outcomes. Much of this recreational fishing for

\footnotetext{
* Corresponding author at: Department of Marine Sciences, University of South Alabama, LSCB Room 25, Mobile, AL 36688, USA.

E-mail addresses: mdrymon@disl.org (J.M. Drymon), s.scyphers@northeastern.edu (S.B. Scyphers).
} 
sharks is catch and release, where anglers are motivated by the challenge and excitement of catching a large fish [15]. These anglers tend to be well-informed on issues regarding shark conservation [12], and among avid shark-targeting anglers, positive attitudes towards sharks and their conservation prevail [16]. As recreational shark catch-and release fisheries continue to increase in popularity, angler's advocacy for sharks [17] and potentially their interest in sustainable shark fisheries, is likely to increase, potentially counteracting the negative stereotype that has been traditionally perpetuated.

Although the consequences of commercial fisheries are often more widely publicized, recreational fisheries have the potential to influence long-term population trends and anglers play a critical role in managing for sustainability [18-20]. For example, the global recreational fishery for bonefish (Albula spp.) is almost exclusively catch-and-release, a practice driven in part by the strong conservation ethic among anglers [21,22]. Florida supports an immense recreational fishery, a growing proportion of which is targeting sharks $[12,15]$. Recent work examining the risk perceptions and conservation ethics demonstrates that this group of anglers are knowledgeable regarding shark conservation, yet may underestimate the impact of recreational fishing on shark populations [12]. To gauge support among these anglers, and to identify the most powerful predictors of their willingness to donate to shark 1) conservation and protection, or 2) fisheries sustainability funds, a survey was distributed to Florida recreational anglers. Given the increase in popularity of recreational shark fishing, it was hypothesized that recreational anglers may be more supportive of fisheries sustainability initiatives compared to initiatives focused solely on conservation and protection.

\section{Methods}

\subsection{Survey instrument and data collection}

To understand Florida angler's attitudes and perceptions towards large coastal sharks, a survey of recreational license holders in the State of Florida was conducted. License holder information was obtained from the Florida Fish and Wildlife Conservation Commission (FWC) in February of 2013. The original dataset contained information from 995,925 licensees and included all license types. That dataset was reduced to include only Florida residents older than 18 years of age with recreational saltwater fishing licenses. Recreational saltwater fishing licenses were defined as either saltwater fishing only, saltwater/freshwater combination, or a Gold Sportsman's license, which includes saltwater fishing alongside hunting and other activities. The final survey population included 362,239 license-holders, from which a random sample of 5000 was drawn. The online survey was designed and distributed to the random sample of 5000 licensees using Qualtrics Survey Research Suite. All survey recipients were asked a series of questions across the following categories: 1) fisher behavior and policy awareness, 2) shark life history knowledge, 3) attitudes, beliefs and perceptions, and 4) shark fishing activities, among others [Fig. A1]. A branching survey design with a complimentary series of questions designed to quantify angler willingness to donate to a fund for 1) shark protection and conservation or 2) shark fisheries sustainability was used. These two hypothetical funds were chosen to test for potential differences in anglers' willingness to support either distinct initiative. For both versions, anglers were presented this question as a dichotomous choice [23], and could 1) choose not to donate, or 2) choose to donate the dollar value presented. The specific dollar value presented to each

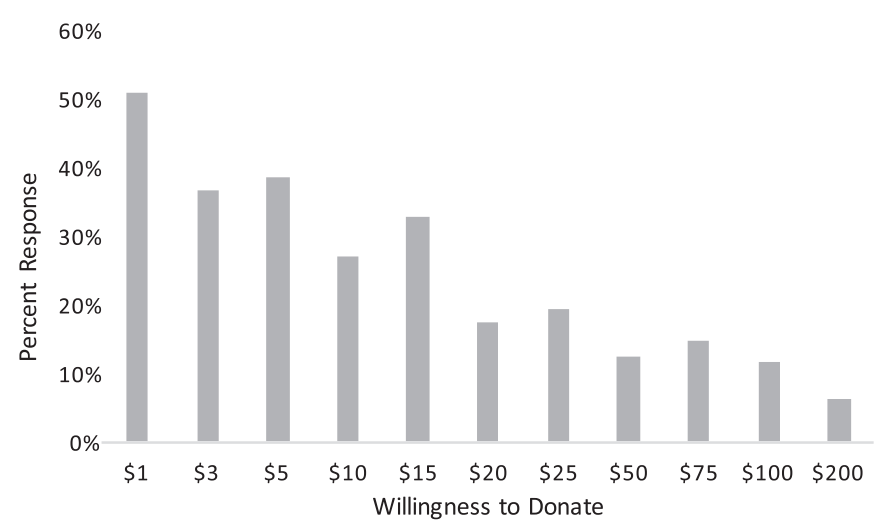

Fig. 1. The percentage of anglers willing to donate to a hypothetical shark protection and conservation (version 1) or a shark fisheries sustainability (version 2) fund. Values are pooled across both surveys.

respondent (either $\$ 1, \$ 3, \$ 5, \$ 10, \$ 15, \$ 20, \$ 25, \$ 50, \$ 75, \$ 100$, $\$ 200)$ was randomly assigned across all surveys. The survey was active for two weeks with email reminders sent every $2-3$ days.

\subsection{Statistical analyses}

Data from Qualtrics were imported into the Statistical Package for the Social Sciences (SPSS, v. 23) for analyses. Survey version was included as an independent variable. Bivariate correlations and treebased classification models using the Chi-squared Automatic Interaction Detection (CHAID) growing method were used to quantify the most powerful factors predicting an angler's willingness to donate (dependent variable) [24]. The CHAID growing method evaluates the explanatory power of the potential predictors, while merging categories that aren't significantly different with respect to the dependent variable. The strongest predictor is placed at the top of the classification tree, with subsequent splits demonstrating variation in the preceding variables. Analyses included 13 potential predictors (independent variables), centered on demographics (age, gender, education and income), knowledge of sharks (species identification, biology/ecology), perception of sharks (their ecosystem role, their historical abundance) and beliefs regarding sharks (fear of sharks, threat posed by sharks to recreational fishing opportunities, thoughts on seeing a shark in the wild). For all tests, $\mathrm{p} \leq 0.05$ was considered significant.

\section{Results}

521 surveys were completed resulting in a response rate of $10 \%$. Demographics of the subsampled population were largely reflective of the survey population. Respondents were middle age with a mean age of 47 years (42 in survey population), $78 \%$ male (76\% male in survey population), and $92 \%$ white ( $91 \%$ white in survey population) [Table A1].

Overall, 25.5\% ( $\mathrm{n}=151)$ of respondents were willing to donate, and donation context (shark protection and conservation vs. shark fisheries sustainability) was not a significant factor. As donation context was not significant, responses from the two surveys were pooled for subsequent analyses. The amount anglers were willing to donate was variable, and ranged from the lowest $(\$ 1)$ to the highest $(\$ 250)$ value presented; that said, the largest decrease between choices was seen between $\$ 15$ and $\$ 20$, suggesting a threshold. This trend in the amount anglers were willing to donate was well explained by a linear decrease in the number 
Table 1

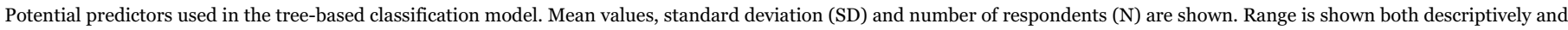
as a value. Correlations (Pearson, r) between the potential predictors and anglers' willingness to donate are shown. Significant correlations and marked with an asterisk.

\begin{tabular}{|c|c|c|c|c|c|c|}
\hline Survey Component & Mean & SD & $\mathbf{N}$ & Range & $\mathbf{r}$ & $\mathbf{p}$ \\
\hline \multicolumn{7}{|l|}{ Demographics } \\
\hline Age & 46.88 & 13.03 & 630 & $18-79$ & -0.003 & 0.935 \\
\hline Gender & 1.78 & 0.41 & 630 & female $=1$, male $=2$ & -0.017 & 0.678 \\
\hline Education & 3.83 & 0.90 & 487 & $\begin{array}{l}\text { 1-5 (less than high school - advanced } \\
\text { degree) }\end{array}$ & 0.078 & 0.089 \\
\hline Income & 3.66 & 1.25 & 442 & $\begin{array}{l}1-6 \text { ( less than } \$ 25,000 \text { - more than } \\
\$ 250,000)\end{array}$ & 0.021 & 0.662 \\
\hline \multicolumn{7}{|l|}{ Knowledge } \\
\hline $\begin{array}{l}\text { Knowledge/ability to identify shark species found in the US Gulf of Mexico and South } \\
\text { Atlantic waters }\end{array}$ & 3.53 & 0.98 & 633 & 1-5 (expert - unfamiliar) & -0.068 & 0.101 \\
\hline Life history knowledge & 0.81 & 0.27 & 621 & $0-1$ (higher number $=$ more knowledge)** & 0.164 & $<0.001^{*}$ \\
\hline \multicolumn{7}{|l|}{ Ecosystem Role } \\
\hline $\begin{array}{l}\text { What effect would completely removing large coastal sharks have on the health of } \\
\text { coastal ecosystems? }\end{array}$ & 4.60 & 0.78 & 624 & $1-5$ (very beneficial - very harmful) & 0.200 & $<0.001^{*}$ \\
\hline Relative to 100 years ago, how do current large coastal shark abundances compare? & 2.72 & 0.64 & 616 & 1-3 (more abundant - less abundant) & 0.150 & $<0.001^{*}$ \\
\hline I think sharks are essential to maintaining the balance of nature. & 1.03 & 0.18 & 590 & $1=$ true, $2=$ false & -0.109 & $0.009^{*}$ \\
\hline Sharks keep fisheries healthy by keeping other predator populations under control. & 1.18 & 0.38 & 587 & 1 =true, $2=$ false & -0.120 & $0.004^{*}$ \\
\hline \multicolumn{7}{|l|}{ Beliefs } \\
\hline $\begin{array}{l}\text { I think a growing large coastal shark population would threaten recreational fishing } \\
\text { opportunities. }\end{array}$ & 1.74 & 0.44 & 589 & $1=$ true, $2=$ false & 0.239 & $<0.001^{*}$ \\
\hline I would be afraid if large sharks were in nearby coastal waters. & 1.70 & 0.46 & 589 & $1=$ true, $2=$ false & 0.166 & $<0.001^{*}$ \\
\hline Seeing a shark in the wild would be one of the greatest outdoor experiences of my life. & 1.63 & 0.48 & 592 & $1=$ true, $2=$ false & -0.273 & $<0.001^{*}$ \\
\hline
\end{tabular}

** mean value from three "True/False" questions

of anglers willing to donate at the highest values presented $\left(\mathrm{R}^{2}=0.90\right)$ [Fig. 1].

Several factors encompassing knowledge and beliefs regarding sharks were significantly correlated to angler willingness to donate. Anglers who had greater knowledge of shark life history ( $\mathrm{r}=0.164, \mathrm{p}<$ 0.001 ) were more likely to donate. These anglers also held beliefs that sharks contribute to healthy coastal ecosystems by maintaining the balance of nature $(\mathrm{r}=-0.109, \mathrm{p}=0.009)$ and keeping other predator populations under control $(\mathrm{r}=-0.120, \mathrm{p}=0.004)$. Anglers who identified shark populations as relatively depleted compared to 100 years ago $(\mathrm{r}=0.150, \mathrm{p}<0.001)$ and noted that the complete removal of sharks would be harmful to coastal ecosystems $(r=0.200, p<0.001)$ were more likely to donate. This same group of anglers don't see sharks as a threat to recreational fishing opportunities $(r=0.239, \mathrm{p}<0.001)$, don't fear the presence of sharks in nearby coastal waters $(\mathrm{r}=0.166, \mathrm{p}<0.001)$, and believe seeing a shark in the wild would be one of the greatest experiences of their life $(r=-0.273, p<0.001)$ [Table 1].

Classification tree analysis showed that among anglers who agreed with the statement "seeing a shark in the wild would be on the greatest outdoor experiences of my life", willingness to donate was significantly higher $(41.4 \%, n=89)$. Furthermore, highest support was shown by a subset of these respondents who occasionally target sharks during recreational fishing trips $(65.8 \%, \mathrm{n}=25)$. Conversely, those anglers who don't value seeing a shark in the wild, but believe that a growing large coastal shark population threatens recreational fishing opportunities, were near unanimous in their unwillingness $(94.0 \%, \mathrm{n}=126)$ to donate to either fund [Fig. 2].

\section{Discussion}

Overall, 1 in 4 people surveyed expressed willingness to donate to either a shark conservation and protection fund, or a shark sustainable fisheries fund. Comparisons with other studies estimating willingness to support species conservation suggests that these values are relatively low. For example, visitors to the Doñana National Park in Spain were asked to valuate 15 species, ranging from charismatic (Iberian lynx Lynx pardinus and imperial eagle Aquila adalberti) to those that generate fear (Grass snake Natrix natrix and endemic spider Donacosa merlini), yet only $27.4 \%$ of survey respondents were unwilling to pay for species conservation projects [25]. Similarly, only $19 \%$ and $25 \%$ of visitors surveyed at the Galapagos National Park were unwilling to donate to conservation efforts for green turtle (Chelonia mydas) and scalloped hammerhead (Sphyrna lewini), respectively [26]. This disparity between visitors to the Galapagos National Park and the Florida anglers currently surveyed may simply reflect demographic differences between the two groups of respondents. For example, when asked why they were unwilling to donate, many respondents in the current study cited lack of disposable income. This contrasts with those surveyed in the Galapagos National Park, who were characterized as "higher income individuals" [26]. Furthermore, respondents from the Galapagos National Park were primarily female (58\%) [26]. The current survey is representative of the population of Florida anglers, who are primarily middleaged men. Previous findings suggest women and younger-aged individuals are more likely to support shark conservation than men and older individuals [27]. The stark differences between these two groups of survey participants illustrates the importance and challenge of designing conservation initiates that are inclusive and resonate with diverse groups of stakeholders.

Willingness to support shark conservation and protection was significantly higher among those individuals who value seeing a shark in the wild. These findings are similar to those of Cárdenas and Lew 


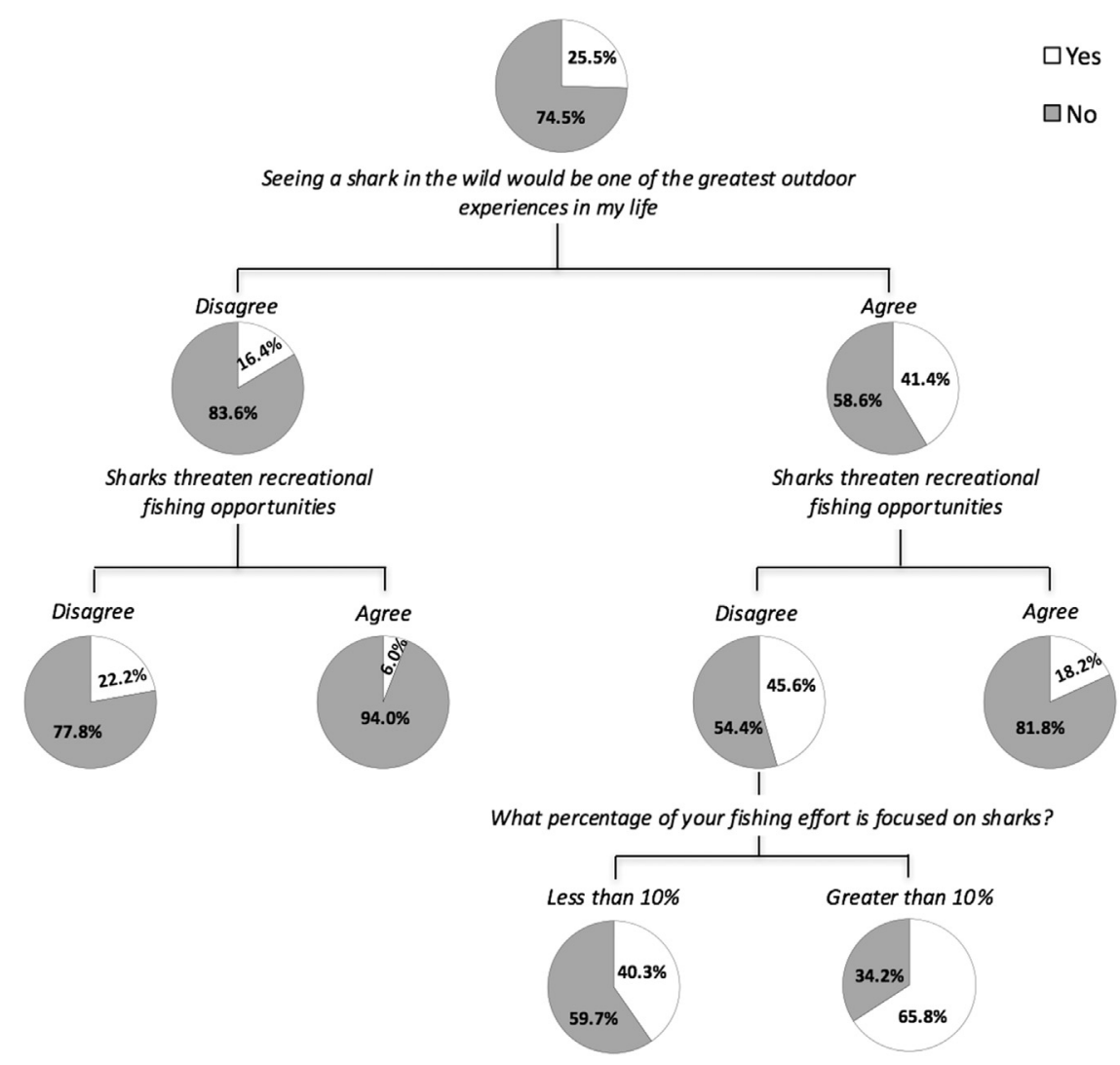

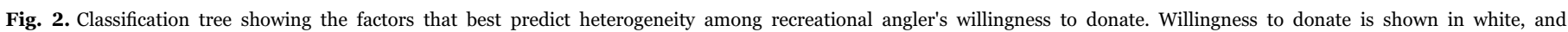
unwillingness to donate is shown in grey. All splits are significant at $\alpha=0.05$.

[26], who showed those most willing to support the protection of scalloped hammerheads were those with a strong desire to see them in the wild. Indeed, interest in the "tourism" (i.e. non-consumptive) value of sharks is on the rise, as evident by the increase in sharkencounter tourism [12,28]. Examples from other taxa demonstrate that conservation benefits can arise from wildlife tourism. For charismatic species like whales and sea turtles, these benefits include increased visitor's willingness-to-pay for conservation [29]. Similarly, when visitors to the Great Barrier Reef Marine Park were asked how much they were willing to pay for " $100 \%$ guaranteed sighting" of various species groups, sharks and rays had values that were nearly as high as whales and dolphins [30]. People are more willing to support the conservation of species they've encountered [31]; as the desire to encounter sharks in the wild increases, so does the potential for shark-encounter tourism to work in tandem with efforts to promote shark conservation.

Highest support for conservation was demonstrated by a subset of recreational anglers who value seeing a shark in the wild, and target them occasionally via hook and line. Recreational angling presents an additional non-extractive use of sharks if catch-and-release is practiced [15], and provides opportunities for encounters with sharks that aren't available for species like whales and turtles. Recreational catch-and-release anglers can be strong proponents of conservation efforts [12,14,15,32], often conceiving and subsequently enacting voluntary conservation measures [33]; these "softer" approaches have been successful for species like muskellunge (Esox masquinongy) [34,35] and bonefish (Albula vulpes) [21]. As recreational fishing for sharks continues to increase in popularity, a similar conservation-oriented ethos may emerge. In Florida, recreational anglers are generally accepting of management measures that protect sharks, particularly those that don't restrict their ability to fish. While these anglers are well informed on issues relating to shark conservation, they perceive the impacts of recreational fishing on shark populations to be minimal [12]. Interest in the recreational angling community to specifically target sharks has increased [14]. Given that recreational specialization is a strong predictor of conservation attitudes and behaviors [36], this group of stakeholders may be valuable partners in developing conservation initiatives that span both conservation/protection and sustainable fisheries.

Conversely, those who don't value seeing sharks in the wild, but rather believe a growing large coastal shark population threatens recreational fishing opportunities, are nearly unanimous in their unwillingness to donate to shark conservation. While recreational anglers in general are often strong proponents of shark conservation (e.g. [32,15]), this subset of anglers highlight the degree to which this assertion is angler-specific. When asked the main reason they would be unwilling to support a hypothetical shark conservation and protection fund, many of these anglers reported recent increases in the number of sharks observed when fishing, similar to recent findings by Gallagher et al. [12]. Many of these anglers are likely to have experienced depredation they attribute to an increasing shark population. Depredation, or the removal of a hooked fish from an angler's line, can increase the potential for human-wildlife conflict, as has been shown for marine mammals like sea lions (Zalophus californianus) [37] and killer whales (Orcinus orca) [38]. For Florida's recreational anglers, a similar situation already exists with respect to Goliath Grouper (Epinephalus itajara), where the majority of respondents 
agreed with the statement "goliath grouper are eating all the fish on the reef", which was related to personal accounts of goliath grouper depredation [39]. Interestingly, the pervasive belief held by these anglers that there are "too many sharks" and that their populations are increasing, isn't shared across all survey participants. When asked how current shark populations compare to 100 years ago, most respondents in our survey stated that there are fewer sharks now. This link between anglers' perceptions and their willingness to support conservation causes underscores the need for a consistent message regarding the status of shark populations.

Despite the perception among some of the surveyed stakeholders, studies suggest continued declines for many large coastal shark species, both globally [1,2] and across the Gulf of Mexico [40]. This survey of recreational anglers suggests the historically negative perception of sharks may be shifting, albeit slowly. Interestingly, these changing perceptions are marked by a shift in attitudes, from "sharks threaten our safety" to "sharks threaten our fishing opportunities." These findings identify the stakeholders most likely to engage in support for shark conservation, while highlighting user conflicts that need to be overcome for conservation efforts to be most effective. Specifically, outreach initiatives aimed at reaching anglers who perceive shark populations to be increasing are recommended.

\section{Acknowledgements}

We sincerely thank the many Florida recreational anglers who participated in this survey, and the State of Florida's Fish and Wildlife Commission for providing access to the license database. This research did not receive any specific grant from funding agencies in the public, commercial, or not-for-profit sectors. SS was funded by a Science, Engineering, and Education for Sustainability (SEES) Fellowship from the National Science Foundation (OCE-1215825). We thank Austin Gallagher and anonymous reviewers for comments that strengthened this manuscript. This research was approved by the Institutional Review Boards at the University of South Alabama and Northeastern University (IRB\# 13-07-16).

\section{Appendix A}

See Table A1 and Fig. A1.

Table A1

Breakdown of demographic variables from the 521 respondents.

\begin{tabular}{|c|c|c|}
\hline Socio-demographic variables & Frequency & Percent \\
\hline \multicolumn{3}{|l|}{ Gender } \\
\hline $\mathrm{F}$ & 140 & $22 \%$ \\
\hline M & 489 & $78 \%$ \\
\hline \multicolumn{3}{|l|}{ Age } \\
\hline Less than 21 & 25 & $4 \%$ \\
\hline $22-30$ & 63 & $10 \%$ \\
\hline $31-40$ & 85 & $13 \%$ \\
\hline $41-50$ & 173 & $27 \%$ \\
\hline $51-64$ & 261 & $41 \%$ \\
\hline $65+$ & 23 & $4 \%$ \\
\hline \multicolumn{3}{|l|}{ Education } \\
\hline Grade 12 or less & 1 & $0 \%$ \\
\hline High school diploma or GED & 31 & $6 \%$ \\
\hline Associate/technical/college coursework & 147 & $30 \%$ \\
\hline Bachelor's degree & 177 & $36 \%$ \\
\hline Advanced degree (MS, $\mathrm{PhD}, \mathrm{MD}$, etc) & 131 & $27 \%$ \\
\hline \multicolumn{3}{|l|}{ Income } \\
\hline Less than $\$ 25,000$ & 12 & $3 \%$ \\
\hline$\$ 25,000-\$ 50,000$ & 63 & $14 \%$ \\
\hline$\$ 50,000-\$ 100,000$ & 139 & $31 \%$ \\
\hline$\$ 100,000-\$ 150,000$ & 124 & $28 \%$ \\
\hline$\$ 150,000-\$ 250,000$ & 58 & $13 \%$ \\
\hline More than $\$ 250,000$ & 46 & $10 \%$ \\
\hline
\end{tabular}




\title{
Shark Life History Knowledge
}

1. In general, sharks are faster/slower growing than other marine fish. (T/F)

2. In general, sharks produce more/fewer off spring than other marine fish. (T/F)

3. In general, sharks reach maturity at an older/younger age than most marine fish. (T/F)

\section{Attitudes, Beliefs and Perceptions}

4. Seeing a shark in the wild would be one of the greatest outdoor experiences of my life. (T/F)

5. I think sharks are essential to maintaining the balance of nature. (T/F)

6. Sharks keep fisheries healthy by keeping other predator populations under control. (T/F)

7. I think a growing large coastal shark population would threaten recreational fishing opportunities. (T/F)

8. I would be afraid if large sharks were in nearby coastal waters. (T/F)

9. What effect would completely removing large coastal sharks have on the health of coastal ecosystems? (1

-5 , very beneficial to very harmful)

10. How would you describe the current overall health of large coastal shark populations? $(A+$ to $F)$

11. Relative to 100 years ago, how do current large coastal shark abundances compare? (More now; Fewer now; About the same)

11b. If fewer, what percentage remain?

\section{Economics}

12. If the State of Florida allowed saltwater fishers to make a donation in the amount listed below to a Shark Conservation and Protection Fund (or Shark Fisheries Sustainability Fund) when purchasing an annual fishing license, would you donate? $(\$ 1, \$ 3, \$ 5, \$ 10, \$ 15, \$ 20, \$ 25, \$ 50, \$ 75, \$ 100, \$ 200$, I would not donate)

12.b If no, what is the main reason you would not be willing to support the Fund?

\section{Shark Fishing Activities}

13. What percentage of your effort is focused on catching large coastal sharks?

\section{Demographics}

\author{
14. Age \\ 15. Gender \\ 16. Highest level of education
}

17. Annual income

Fig. A1. Questions from the recreational angler survey used in the current analysis.

\section{References}

[1] N.K. Dulvy, S.L. Fowler, J.A. Musick, R.D. Cavanagh, P.M. Kyne, L.R. Harrison, J.K. Carlson, L.N. Davidson, S.V. Fordham, M.P. Francis, C.M. Pollock, C.A. Simpfendorfer, G.H. Burgess, K.E. Carpenter, L.J.V. Compagno, D.A. Ebert, C. Gibson, M.R. Heupel, S.R. Livingston, J.C. Sanciangco, J.D. Stevens, S. Valenti, W.T. White, Extinction risk and conservation of the world's sharks and rays, Elife (2014) e00590.

[2] B. Worm, B. Davis, L. Kettemer, C.A. Ward-Paige, D. Chapman, M.R. Heithaus, S.T. Kessel, S.H. Gruber, Global catches, exploitation rates, and rebuilding options for sharks, Mar. Policy 40 (2013) 194-204.

[3] J.M. Hoenig, S.H. Gruber, Life-history patterns in the elasmobranchs: implications for fisheries management, NOAA Tech. Rep. 90 (1) (1990) 16.

[4] C.A. Ward-Paige, D.M. Keith, B. Worm, H.K. Lotze, Recovery potential and conservation options for elasmobranchs, J. Fish Biol. 80 (2012) 1844-1869.

[5] C.A. Simpfendorfer, M.R. Heupel, W.T. White, N.K. Dulvy, The importance of research and public opinion to conservation and management of sharks and rays: a synthesis, Mar. Freshw. Res. 62 (2011) 518-527.

[6] H. Lotze, M. Coll, A. Magera, C. Ward-Paige, L. Airoldi Recovery of marine animal populations and ecosystems, Trends Ecol. Evol., 26(11), pp. 595-605.

[7] L.A. Friedrich, R. Jefferson, G. Glegg, Public perceptions of sharks: gathering support for shark conservation, Mar. Policy 47 (2014) 1-7.
[8] R.C. Garla, R.H.A. Freitas, J.F. Calado, G.B.C. Paterno, A.R. Carvalho, Public awareness of the economic potential and threats to sharks of a tropical oceanic archipelago in the western South Atlantic, Mar. Policy 60 (2015) 128-133.

[9] B.A. Muter, M.L. Gore, K.S. Gledhill, C. Lamont, C. Huveneers, Australian and US News media portrayal of sharks and their conservation, Conserv. Biol. 27 (1) (2012) 187-196.

[10] C. McCagh, J. Sneddon, D. Blache, Killing sharks: the media's role in public and political response to fatal human-shark interactions, Mar. Policy 62 (2015) 271-278.

[11] J.R. O’Bryhim, E.C.M. Parsons, Increased knowledge about sharks increases public concern about their conservation, Mar. Policy 56 (2015) 43-47.

[12] A.J. Gallagher, S.J. Cooke, N. Hammerschlag, Risk perception and conservation ethics among recreational anglers targeting threatened sharks in the subtropical Atlantic, Endanger. Species Res. 29 (2015) 81-93.

[13] C.L. Neff, J.Y. Yang, Shark bites and public attitudes: policy implications from the first before and after shark bite survey, Mar. Policy 38 (2013) 545-547.

[14] S.J. Cooke, Z.S. Hogan, P.A. Butcher, M.J.W. Stokesbury, R. Raghavan, A.J. Gallagher, N. Hammerschlag, A.J. Danylchuk, Angling for endangered fish: conservation problem or conservation action?, Fish Fish. (2014). http://dx.doi.org/ $10.1111 /$ faf.12076.

[15] D. Shiffman, N. Hammerschlag, An assessment of the scale, practices, and conservation implications of Florida's charter boat-based recreational fishery, Fisheries 39 (9) (2014) 395-407. 
[16] K. McClellan Press, J. Mandelman, E. Burgess, S.J. Cooke, V.M. Nguyen, A.J. Danylchuk, Catching sharks: recreational saltwater angler behaviours and attitudes regarding shark encounters and conservation, Aquat. Conserv.: Mar. Freshw. Ecosyst. (2015).

[17] M. Heard, S. Sutton, P. Rogers, C. Huveneers, Actions speak louder than words: tournament angling as an avenue to promote best practice for pelagic shark fishing, Mar. Policy 64 (2016) 168-173.

[18] F.C. Coleman, W.F. Figueira, J.S. Ueland, L.B. Crowder, The impact of United States recreational fisheries on marine fish populations, Science 305 (5692) (2004) 1958-1960.

[19] R. Myers, J. Taylor, M. Allen, T.F. Bonvechio, Temporal trends in voluntary release of largemouth bass, N. Am. J. Fish. Manag. 28 (2) (2008) 428-433.

[20] E.F. Granek, E.M.P. Madin, M.A. Brown, W. Figueira, D.S. Cameon, Z. Hogan, G. Kristianson, P. de Villiers, J.E. Williams, J. Post, S. Zahn, R. Arlinghaus, Engaging recreational fishers in management and conservation: global case studies, Conserv. Biol. 22 (5) (2008) 1125-1134.

[21] D. Policansky, Catch and release fishing - a historical perspective, in: T.J. Pitcher, C.E. Hollingworth (Eds.), Recreational Fisheries: Ecological, Economic and Social Evaluation, Blackwell Science Ltd, Oxford, UK, 2002, pp. 74-94.

[22] S.J. Cooke, A.J. Danylchuk, S.E. Danylchuk, C.D. Suski, T.L. Goldberg, Is catchand-release recreational angling compatible with no-take marine protected areas?, Ocean Coast. Manag. 49 (2006) 342-354.

[23] D.K. Lew, Willingness to pay for threatened and endangered marine species: a review of the literature and prospects for policy use, Front. Mar. Sci. 2 (96) (2015) $1-17$.

[24] A. Agresti, Logit models for multinomial responses. Categorical Data Analysis, Second Edition, 2002, pp. 267-313.

[25] B. Martín-López, C. Montes, J. Benayas, The non-economic motives behind the willingness to pay for biodiversity conservation, Biol. Conserv. 139 (1) (2007) 67-82.

[26] S.A. Cardenas, D.K. Lew, Factors influencing willingness to donate to marine endangered species recovery in the Galapagos National Park, Ecuador, Front. Mar. Sci. 3 (2016) 60.

[27] J.G. Myrick, S.D. Evans, Do PSAs take a bite out of Shark Week? The effects of juxtaposing environmental messages with violent images of shark attacks, Sci. Commun. 36 (5) (2014) 544-569.
[28] A.J. Gallagher, N. Hammerschlag, Global shark currency: the distribution, frequency, and economic value of shark ecotourism, Curr. Issues Tour. 14 (8) (2011) 797-812.

[29] C. Wilson, C. Tisdale, Conservation and economic benefits of wildlife-based marine tourism: sea turtles and whales as case studies, Hum. Dimens. Wildl. 8 (1) (2003) 49-58.

[30] M. Farr, N. Stoeckl, R.A. Beg, The non-consumptive (tourism) 'value 'of marine species in the Northern section of the Great Barrier Reef, Mar. Policy 43 (2014) 89-103.

[31] C. Tisdale, C. Wilson, Wildlife-based tourism and increased support for nature conservation financially and otherwise: evidence from sea turtle ecotourism at Mon Repos, Tour. Econ. 7 (3) (2001) 233-249.

[32] A.M. Lynch, S.G. Sutton, C.A. Simpfendorfer, Implications of recreational fishing for elasmobranch conservation in the Great Barrier Reef Marine Park, Aquat. Conserv.: Mar. Freshw. Ecosyst. 20 (3) (2010) 312-318.

[33] S.J. Cooke, C.D. Suski, R. Arlinghaus, A.J. Danylchuk, Voluntary institutions and behaviors as alternatives to formal regulations in recreational fisheries management, Fish Fish. 14 (2013) 439-457.

[34] A.H. Fayram, A comparison of regulatory and voluntary release of muskellunge and walleyes in northern Wisconsin, N. Am. J. Fish. Manag. 23 (2) (2003) 619-624.

[35] S.J. Landsman, H.J. Wachelka, C.D. Suski, S.J. Cooke, Evaluation of the physiology, behavior, and survival of adult muskellunge (Esox masquinongy) captured and released by specialized anglers, Fish. Res. 110 (2011) 377-386.

[36] C.O. Oh, R.B. Ditton, Using recreation specialization to understand conservation support, J. Leis. Res. 40 (4) (2008) 556.

[37] T.C. Cook, K. James, M. Bearzi, Angler perceptions of California sea lion (Zalophus californianus) depredation and marine policy in Southern California, Mar. Policy 51 (2015) 573-583.

[38] M.J. Peterson, C. Carothers, Whale interactions with Alaskan sablefish and Pacific halibut fisheries: surveying fishermen perception, changing fishing practices and mitigation, Mar. Policy 42 (2013) 315-324.

[39] G.S. Shideler, D.W. Carter, C. Liese, J.E. Serafy, Lifting the goliath grouper harvest ban: angler perspectives and willingness to pay, Fish. Res. 161 (2015) 156-165.

[40] S.P. Powers, F.J. Fodrie, S.B. Scyphers, J.M. Drymon, R.L. Shipp, W. Stunz, Gulfwide decreases in the size of large coastal sharks documented by generations of fishermen, Mar. Coast. Fish. 5 (1) (2013) 93-102. 